\title{
RESPONSE OF ONION TO DIFFERENT LEVELS OF IRRIGATION WATER AND FERTILIZATION: (I) SOIL MOISTURE CONTENT, GROWTH PARAMETERS AND BULB YIELD
}

Ahmed M. Hassan*

ABSTRACT

This study evaluated of irrigation deficit and NPK fertilization on growth and yield of onion grown in the semi arid area of Libya. A field experiment was conducted using onion grown in northeast Libya at Elbyda (البيضاء) in 2011 and 2012. Four irrigation deficits and four NPK fertilization rates were arranged in a randomized split-plot design. Irrigation treatments were a ratio of crop evapotranspiration (ET) as: 1.0 ET, 0.85 ET, 0.75 ET, and 0.65 ET. Fertilizer treatments were 100, 75, 50 , and $0 \%$ of the applied recommended rate of NPK. The results showed that the interaction between different water levels and NPK rates had no significant effects on growth and yield parameters when transit from 100 to $85 \%$ ET or when decreasing NPK rates from 100 to $75 \%$. The growth and yield parameters (fresh bulb weight, bulb diameter, bulb length, and bulb yield) where non significantly decreased (2.2 and 14.6\%), (3.2 and $13.8 \%)$, (3.7 and 1.9\%), and (2.1 and 14.6\%) in 2011 and (0.12 and 9.6 $\%)$, (2.8 and $3.5 \%)$, (0.27 and $2.6 \%)$, and (0.12 and 9.6\%) in 2012, respectively when compared to $100 \%$ ET or $75 \%$ NPK rate. An optimal treatment was statistically developed based on crop response in deficit irrigation and NPK fertilization rate to achieve maximum yield of onion. Keywords: water deficit, NPK fertilization, growth parameters, yield, onion, soil moisture content

\section{INTRODUCTION}

I rrigation water and nutrient stresses are two major constraints in agriculture production and lower yield in many countries. Water stress affects crop growth and productivity depending on drought tolerance, drought resistance or growth periods of the crops. To improve water productivity, there is a growing interest in deficit irrigation. Deficit irrigation is irrigating the root zone with less water than required for evapotranspiration (Zegbe-Dominguez et al., 2003). Under conditions of scarce water supply, deficit irrigation can provide greater economic returns than maximizing yields per unit of water. To manage plant water * Assis. Prof., Ag. Eng. Dept., Faculty of Ag., Cairo Univ. 
stress it is necessary to carefully schedule irrigation which consists of determining the amount and timing of irrigation applications (Martin et al., 1990). The water saving strategy of reducing irrigation rates at predetermined developmental stages where deficits would not severely impact productivity is called regulated deficit irrigation (RDI) (Kirda, 2002; Mpelasoka et al., 2001). There are two main methods to schedule irrigation; first by replacing crop evapotranspiration (ETC) fractions according to a soil water balance, or second by triggering irrigation according to water content status of the soil and allowable depletion levels (Hanson et al., 2000). One of the difficulties of irrigation scheduling using crop evapotranspiration $\left(E T_{c}\right)$ is that local crop coefficients are needed, and these vary according to crop varieties, plant densities, row configurations and planting dates (Enciso et al., 2007). The adoption of deficit irrigation implies appropriate knowledge of crop evapotranspiration (ET), crop response to water deficits, including the identification of critical crop growth periods, and the economic impacts of yield reduction strategies; therefore growers may have difficulty in using it (Pereira et al., 2002).

A positive approach to attain the goal of improving water use efficiency (WUE) is deficit irrigation (Topcu et al., 2007), a water saving strategy under which crops are deliberately allowed to sustain some degree of water deficit and yield reduction (Pereira et al., 2002). WUE can be optimized by the adoption of more efficient irrigation practices (Costa et al., 2007). Kirda (2000) stated that properly practiced deficit irrigation may increase crop quality. For instance, the protein content and baking quality of wheat, the length and strength of cotton fibers, and the sucrose concentration of sugar beet and grape have been reported to increase under deficit irrigation. Deficit irrigation is a way of maximizing water use efficiency for higher yields per unit of irrigation water applied: the crop is exposed to a certain level of water stress either during a particular period or throughout the whole growing season (Kirda, 2000). Moreover, studies have shown that water deficit during certain stages of growing season improves fruit quality, although water limitations may also 
determine fruit yield losses (Patanè and Cosentino, 2010). Some scientists have found bigger yield differences when the onion crop is stressed at certain growing stages such as the study of Martin de Santa Olalla et al. (2004) who showed that inducing water deficits at the bulbification and ripening stages lead to significant differences on yields. While Enciso et al. (2009) stated that yields were not affected when water applications were reduced from $100 \%$ to $75 \% E T_{c}$. Onions under deficit irrigation have lower evapotranspiration rates and yields (Sammis et al., 2000). For optimum yield, it is necessary to prevent the crop from experiencing water deficit, especially during the bulb development stage. During the vegetative and ripening periods, the crop appears to be less sensitive to water deficit. Nitrogen $(\mathrm{N})$ and phosphorus $(\mathrm{P})$ stresses lead to the change of growth, physiology and water use of plants (Lovelock et al., 2006). Decreasing the water content in a soil decreased $\mathrm{K}$ uptake by onion roots; the drought resulted in an increasingly steep $\mathrm{K}$ gradient around the root (Kuchenbuch et al., 1986). In soybean, the $K$ content of the xylem sap decreased with decreasing water potential (McQuate et al., 1986). Application of nitrogen and potassium influenced the different growth components of onion at all the stages of crop growth.

In this paper, the objective is investigating the effects of different irrigation water levels and different levels of NPK fertilization upon growth parameters and total bulb yield of onion.

\section{MATERIALS AND METHODS}

\section{Study area}

The study was conducted at the experimental farm of Horticultural Department, Faculty of Agriculture, Omar El-Mukhtar University. The experiment was conducted in 2011 and 2012. Some chemical and physical characteristics of the experimental field soil are shown in tables (1) and (2). Also table (3) shows some physical analysis of irrigation water used in the experiment and table (4) shows the average monthly climatic data (1946 - 2011) from May to September. 
Table (1): Some chemical analyses of soil samples.

\begin{tabular}{|c|c|c|c|c|c|c|c|c|}
\hline \multirow{2}{*}{$\begin{array}{c}\text { Depth, } \\
\mathbf{c m}\end{array}$} & $\begin{array}{c}\mathbf{E C}_{\text {e1:1 }} \\
\mathbf{d S} / \mathbf{m}\end{array}$ & $\mathbf{C a}^{++}$ & $\mathbf{M g}^{++}$ & $\mathbf{N a}^{+}$ & $\mathbf{K}^{+}$ & $\mathbf{C l}^{-}$ & $\begin{array}{c}\mathbf{H C O}_{3}^{-} \\
+ \\
\mathbf{C O}_{3}^{--}\end{array}$ & $\mathbf{S O}_{4}^{-{ }^{--}}$ \\
\hline $\mathbf{0 - 3 0}$ & 0.86 & 2.4 & 1.5 & 4.5 & 0.3 & 3.5 & 2.2 & 2.8 \\
\hline $\mathbf{3 0 - 6 0}$ & 0.76 & 2.0 & 1.4 & 3.8 & 0.4 & 3.4 & 2.1 & 2.1 \\
\hline
\end{tabular}

Table (2): Some physical analyses of soil samples.

\begin{tabular}{|c|c|c|c|c|c|c|c|}
\hline \multirow{2}{*}{$\begin{array}{l}\text { Depth, } \\
\text { cm }\end{array}$} & \multicolumn{3}{|c|}{$\begin{array}{c}\text { Particle size distribution } \\
(\%)\end{array}$} & \multirow{2}{*}{$\begin{array}{l}\text { Texture } \\
\text { class }\end{array}$} & \multirow{2}{*}{$\begin{array}{l}\text { F.C } \\
\%\end{array}$} & \multirow{2}{*}{$\begin{array}{l}\text { W.P } \\
\%\end{array}$} & \multirow{2}{*}{$\begin{array}{c}\text { Soil Bulk } \\
\text { Density, } \mathbf{g} / \mathrm{cm}^{3}\end{array}$} \\
\hline & Sand & Silt & Clay & & & & \\
\hline 0 - 30 & 28.2 & 34.1 & 37.7 & $\mathrm{Cl}_{c}$ & 35.2 & 21.1 & 1.29 \\
\hline $30-60$ & 22.3 & 38.0 & 39.7 & Clay loam & 37.5 & 22.2 & 1.27 \\
\hline
\end{tabular}

Table (3): Some chemical analyses of water samples.

\begin{tabular}{|c|c|c|c|c|c|c|c|}
\hline EC & \multicolumn{4}{|c|}{ Cations (meq/L) } & \multicolumn{3}{c|}{ Anions (meq/L) } \\
\hline $\mathrm{ds} / \mathrm{m}$ & $\mathrm{Na}^{+}$ & $\mathrm{Ca}^{++}$ & $\mathrm{Mg}^{++}$ & $\mathrm{K}^{+}$ & $\mathrm{HCO}_{3}^{-}$ & $\mathrm{Cl}^{-}$ & $\mathrm{SO}_{4}^{--}$ \\
\hline 0.72 & 3.2 & 2.1 & 1.5 & 0.4 & 2.6 & 3.5 & 1.1 \\
\hline
\end{tabular}

Table (4): Monthly climatic data of the experimental area.

\begin{tabular}{l|ccccc}
\hline \multirow{2}{*}{ Climatic parameters } & \multicolumn{5}{|c}{ Months } \\
& May & Jun. & Jul. & Aug. & Sep. \\
\hline $\mathbf{T}_{\text {minn }}{ }^{\mathbf{0}} \mathbf{C}$ & 13.6 & 16.6 & 18.8 & 19 & 17.8 \\
$\mathbf{T}_{\text {max }},{ }^{\mathbf{0}} \mathbf{C}$ & 24.0 & 27.2 & 28.1 & 28.1 & 26.3 \\
$\mathbf{T}_{\text {ave, }}{ }^{\mathbf{0}} \mathbf{C}$ & 18.8 & 21.9 & 23.5 & 23.6 & 22.1 \\
RH, \% & 59.0 & 58.9 & 61.3 & 62.3 & 62.3 \\
Rainfall, mm/month & 9 & 0 & 0 & 0.7 & 9.8 \\
Wind speed, m/sec & 3.8 & 4.16 & 4.57 & 4.38 & 2.52 \\
Sunshine, h & 10 & 12 & 12 & 12 & 10 \\
\hline
\end{tabular}

\section{Planting and agronomic practices}

Pegou onion (Allium cepa L.) variety was used for the study. Seeds were sown in a nursery on a well prepared seed bed. When seedlings were at the 3 to 4 leaf stage or 12 to $15 \mathrm{~cm}$ height, they were transplanted in the experimental field. Planting was done on furrows of about $25 \mathrm{~cm}$ height and $16 \mathrm{~m}$ length, adopting the recommended spacing of $50 \mathrm{~cm}$ between furrows and $15 \mathrm{~cm}$ between plants with a total of 106 plants per row. A distance of $1 \mathrm{~m}$ was maintained between plots and $1 \mathrm{~m}$ between blocks. Each experimental plot had three rows. The fertilizer sources were urea 
(46\%), Phosphoric acid $\left(\mathrm{P}_{2} \mathrm{O}_{2}, 80 \%\right)$ and liquid Potassium $\left(\mathrm{K}_{2} \mathrm{O} 36 \%\right)$ for Nitrogen $(\mathrm{N})$, Phosphor $(\mathrm{P})$ and Potassium $(\mathrm{K})$, respectively. The half doses of NPK for each treatment were applied after three weeks of transplanting and the remaining half doses of NPK were applied after two months of transplanting manually (table 5). The recommended fertilizers of NPK were $75 \mathrm{~kg} / \mathrm{ha}, 100 \mathrm{~kg} / \mathrm{ha}$ and $50 \mathrm{~kg} / \mathrm{ha}$ for urea, phosphoric acid and liquid potassium, respectively.

Table (5): Production operations and crop growth parameters for the two seasons this study was conducted.

\begin{tabular}{|l|l|l|}
\hline Operation & $\mathbf{2 0 1 1}$ & $\mathbf{2 0 1 2}$ \\
\hline Planting & 29 April 2011 & 23 April 2012 \\
1st fertilizer application & 20 May 2011 & 15 May 2012 \\
2nd fertilizer application & 28 June 2011 & 24 June 2012 \\
Last irrigation & 12 September 2011 & 9 September 2012 \\
Harvest & 27 September 2011 & 26 September 2012 \\
\hline
\end{tabular}

\section{Experimental design}

In this study, four crop water requirements (I) and four NPK fertilization treatments $(\mathrm{F})$ were designed in open field experiment. The water treatments were $\mathrm{I}_{100}=100 \%, \mathrm{I}_{85}=85 \%, \mathrm{I}_{75}=75 \%$ and $\mathrm{I}_{65}=65 \%$ of $\mathrm{ET}_{\mathrm{c}}$ ) and the fertilization treatments were $\mathrm{F}_{100}=100 \%$ dose of NPK, $\mathrm{F}_{75}$ $=75 \%$ dose of NPK, $\mathrm{F}_{50}=50 \%$ dose of NPK, and $\mathrm{F}_{0}=0 \%$ dose of NPK. This experimental plan yielded 16 treatments (i.e. $4 \times 4$ ) and each treatment was replicated three times. The trickle irrigation system was used and the emitters were pressure compensated with a flow rate of 4 $\mathrm{L} / \mathrm{h}$, the emitters were spaced at $20 \mathrm{~cm}$ with polyethylene tubes $(16 \mathrm{~mm}$ in external diameter) with $50 \mathrm{~cm}$ spacing between tubes. The treatment combinations were arranged in a Randomized Split-Block Design with three replications.

\section{Measurements}

\subsection{Determination of crop irrigation water requirement of onion}

The FAO Penman-Monteith method (Allen et al., 1998) was used to calculate the reference evapotranspiration $E T_{o}$ in the CROPWAT Program. Crop water requirements $\left(E T_{c}\right)$ over the growing season were determined from $E T_{o}$ according to the following equation using crop coefficient $K_{c}$ : 


$$
E T_{c}=K_{c} E T_{o}
$$

Where $E T_{c}$ is the crop water requirement, $\mathrm{K}_{\mathrm{c}}$ is the crop coefficient and $E T_{o}$ is the reference evapotranspiration. According to Allen et al., 1998, $\mathrm{Kc}$ of onion is ranged from 0.4 to 1.05 . The total amounts of irrigation water applied (from transplantation to harvest) $\mathrm{I}_{100}, \mathrm{I}_{85}, \mathrm{I}_{75}$, and $\mathrm{I}_{65}$ in this study were respectively 564, 482, 423, and $368 \mathrm{~mm}$ for first year and 582, 494, 436, and $378 \mathrm{~mm}$ for second year. The water requirement was determined for different months based on crop growth stages and climatic data.

\subsection{Soil moisture content}

To determine moisture content for each treatment, Theta-meter instrument was used. The location was defined according to its $\mathrm{x}, \mathrm{y}$ and $\mathrm{z}$ coordinates with respect to the emitter. The sample locations with respect to the $\mathrm{x}$ direction were taken at 0,5 , and $10 \mathrm{~cm}$ for all treatments. With respect to the y-direction, perpendicular to the emitters line, the sample locations were taken at $0,5,10,15,20$, and $25 \mathrm{~cm}$ for all treatments. For each of these locations, moisture content was determined for different layer depths from soil surface, which were $(0-10),(10-20),(20-30),(30-$ $40)$, and $(40-50) \mathrm{cm}$. The initial soil moisture content before water application ranged from 20.3 to $25.7 \%$ by weight.

\subsection{Water use efficiency (WUE)}

Water use efficiency $\left(W U E_{y}, \mathrm{~kg} / \mathrm{m}^{3}\right)$ was calculated as the ratio between total fresh yield at harvest $(\mathrm{kg} / \mathrm{ha})$ and total water used $\left(\mathrm{m}^{3} / \mathrm{ha}\right)($ Lovelli et al., 2007).

\subsection{Plant characteristics and yield}

Measurements on the following growth parameters and bulb characters were recorded during physiological maturity and at harvesting time. Leaf number per plant refers to the total count of leaves per plant at maturity. The length of the longest leaf was measured with meter scale from the base to its apex. Leaf diameter refers to the maximum diameter of the longest leaf and neck thickness was measured at the narrowest point using vernier caliper. Bulb length and diameter refer to the height of the bulb and the average width at the widest point in the middle portion of the mature bulb measured using vernier caliper. Average bulb weight 
computed by weighing ten bulbs together and calculating the average. The data set is the average of ten randomly taken plants in each experimental plot. Total bulb yield was computed based on the weight of matured bulbs yield per plot and converted into hectare base and expressed in ton. Split bulbs percentage was determined by counting the number of split bulbs per plot and expressed in percentage in reference to total number of normal bulbs per plot.

\subsection{Statistical analysis}

Analysis of variance (ANOVA) was performed using two-way ANOVA from MSTAT software. All the treatment means were compared for any significant differences using the Duncan's multiple range tests at significant level of $\mathrm{P}_{0.05}$.

\section{RESULTS AND DISCUSSION}

\section{Soil moisture content}

The percentage of water found in the soil profile at different distances from the emitter at the end of irrigation time tabulated in table (6) and figure (1).

As shown in table (6) and figure (1), the first and the second vertical layers in the X-direction $(0-10 \mathrm{~cm})$ and $(10-20 \mathrm{~cm})$ had 54.2, 54, 51.6, and $49.7 \%$ of the total applied water volume for the treatments $I_{100}, I_{85}, I_{75}$ and $\mathrm{I}_{65}$, respectively, while they had $36.6,37.7,39.3$, and $39.7 \%$ of the total applied water volume in third and forth vertical layers, $(20-30)$ and (30 - 40), for treatments $I_{100}, I_{85}, I_{75}$ and $I_{65}$, respectively. The total applied water volume for all treatments in the last vertical layer had very little percentage of water content. The results showed that the percent of the total applied water volume in both first and second layers decreased with decreasing applied water due to water movement laterally than vertically. The highest water soil content $\left(\mathrm{I}_{100}\right)$ produced greater radius to depth ratio while the reverse was true for the lowest water soil content $\left(\mathrm{I}_{65}\right)$.

In the Y-Z direction as indicated in table (6), the first and the second vertical layers $(0-10 \mathrm{~cm})$ and $(10-20 \mathrm{~cm})$ had $38.3,39.7,37.6$ and $38 \%$ of the total applied water volume for the treatments $\mathrm{I}_{100}, \mathrm{I}_{85}, \mathrm{I}_{75}$, and $\mathrm{I}_{65}$, 
respectively, while the third and the fourth vertical layers, $(20-30 \mathrm{~cm})$ and $(30-40 \mathrm{~cm})$, had $48.5,48.1,50.2$ and $47.1 \%$ of the total applied water volume for the treatments $\mathrm{I}_{100}, \mathrm{I}_{85}, \mathrm{I}_{75}$ and $\mathrm{I}_{65}$, respectively. Thus, in the Y-direction, the third and fourth layers had the maximum water volumes for all treatments because as illustrated in figure (1) the first and the second vertical layers had little soil volume attributed furrow shape, but in the X-direction the first and second layers had the maximum water volumes for all treatments because all layers had the same volume of soil (fig. 1).

A saturated zone below the trickle line was obtained only for treatments $I_{100}, I_{85}$ and $I_{75}$. For the lower soil water contents, there was no saturated zone below the emitter.

Table (6): The percentage of water found in the soil profile of different water treatments.

\begin{tabular}{|c|c|c|c|c|}
\hline \multirow{2}{*}{ Depth, cm } & \multicolumn{4}{|c|}{ Treatments } \\
\cline { 2 - 5 } & $\mathbf{I}_{\mathbf{1 0 0}}$ & $\mathbf{I}_{\mathbf{8 5}}$ & $\mathbf{I}_{\mathbf{7 5}}$ & $\mathbf{I}_{\mathbf{6 5}}$ \\
\cline { 2 - 5 } $\mathbf{0}-\mathbf{X}$ - direction \\
\hline $\mathbf{0}-\mathbf{1 0}$ & 27.8 & 27.5 & 25.9 & 25.0 \\
\hline $\mathbf{1 0}-\mathbf{2 0}$ & 26.4 & 26.5 & 25.7 & 24.7 \\
\hline $\mathbf{2 0}-\mathbf{3 0}$ & 21.1 & 22.8 & 22.5 & 24.1 \\
\hline $\mathbf{3 0}-\mathbf{4 0}$ & 15.5 & 14.9 & 16.8 & 15.6 \\
\hline $\mathbf{4 0}-\mathbf{5 0}$ & 9.2 & 8.3 & 9.1 & 10.6 \\
\hline \multirow{2}{*}{$\mathbf{0}$} & 17.4 & 18.2 & 16.9 & 16.7 \\
\hline $\mathbf{0}-\mathbf{1 0}$ & 20.9 & 21.5 & 20.7 & 21.3 \\
\hline $\mathbf{1 0}-\mathbf{2 0}$ & 27.2 & 27.9 & 28.5 & 27.0 \\
\hline $\mathbf{2 0}-\mathbf{3 0}$ & 21.3 & 20.2 & 21.7 & 20.1 \\
\hline $\mathbf{3 0}-\mathbf{4 0}$ & 13.2 & 12.2 & 12.2 & 14.9 \\
\hline $\mathbf{4 0}-\mathbf{5 0}$ & & \multicolumn{3}{|c|}{} \\
\hline
\end{tabular}




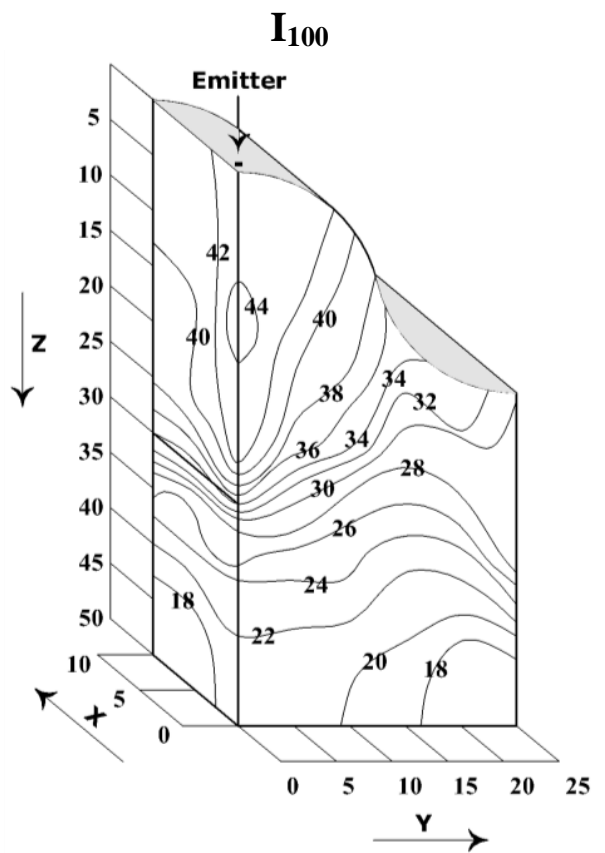

$\mathbf{I}_{75}$

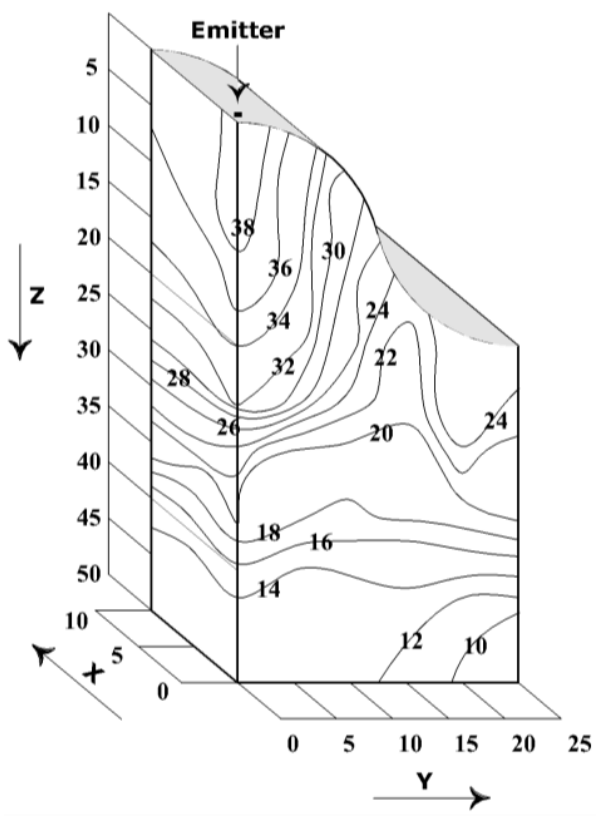

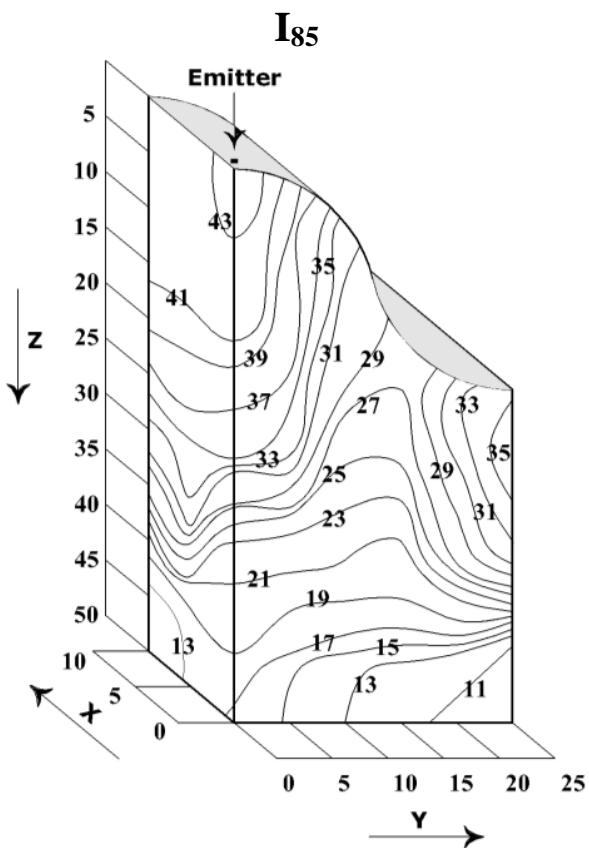

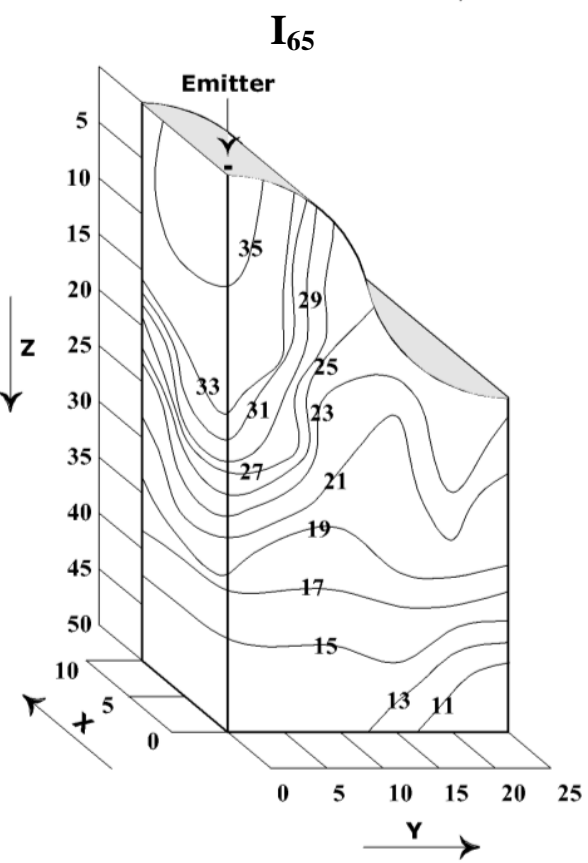

Figure (1): Distributions of water patterns in furrow for the four water treatments. 


\section{Growth parameters of onion}

Table (7) shows the average values of fresh bulb weight, leaf length and diameter, leaves per plant and leaf weight after 60 days from transplanting. The minimum values of fresh bulb weight, leaf weight, leaves per plant, leaf length and diameter were $(6.59 \mathrm{~g}, 23.93 \mathrm{~g}, 5.63$, $34.25 \mathrm{~cm}$ and $0.78 \mathrm{~cm}$ ) found with treatments $\mathrm{I}_{65} \mathrm{~F}_{0}, \mathrm{I}_{65} \mathrm{~F}_{0}, \mathrm{I}_{100} \mathrm{~F}_{0}, \mathrm{I}_{65} \mathrm{~F}_{50}$ and $\mathrm{I}_{65} \mathrm{~F}_{50}$ in 2011 , respectively and were $(6.24 \mathrm{~g}, 29.10 \mathrm{~g}, 5.56,34.56 \mathrm{~cm}$ and $0.70 \mathrm{~cm}$ ) found with treatment $\mathrm{I}_{65} \mathrm{~F}_{0}$ in 2012 , while the maximum values of fresh bulb weight, leaf weight, leaves per plant, leaf length and diameter were $(22.1 \mathrm{~g}, 54.88 \mathrm{~g}, 7.13,45.69 \mathrm{~cm}$ and $1.44 \mathrm{~cm})$ found with treatments $\mathrm{I}_{100} \mathrm{~F}_{100}, \mathrm{I}_{100} \mathrm{~F}_{100}, \mathrm{I}_{100} \mathrm{~F}_{100}, \mathrm{I}_{100} \mathrm{~F}_{100}$ and $\mathrm{I}_{85} \mathrm{~F}_{75}$, respectively in 2011 and were $(23.92 \mathrm{~g}, 56.45 \mathrm{~g}, 7.26,48.67 \mathrm{~cm}$ and $1.42 \mathrm{~cm})$ found with treatment $\mathrm{I}_{100} \mathrm{~F}_{100}$ in 2012.

The results showed that the growth parameters of onion significantly decreased by decreasing water applied except leaf weight and leaves per plant in 2011 and fresh bulb weight and leaf weight in 2012, while fresh bulb weight and leaf weight significantly decreased by decreasing the rate of NPK in 2011 and fresh bulb weight, leaf length and leaf diameter significantly decreased by decreasing the rate of NPK in 2012. The reason for these results is due to decreasing water level decrease the abovementioned measurements.

The interaction of irrigation and NPK levels showed a significant influence on fresh bulb weight in 2011 and 2012. There is no significant influence between treatments $\mathrm{I}_{100} \mathrm{~F}_{100}, \mathrm{I}_{100} \mathrm{~F}_{75}$ and $\mathrm{I}_{85} \mathrm{~F}_{100}$. Treatments $\mathrm{I}_{100} \mathrm{~F}_{75}$ and $\mathrm{I}_{85} \mathrm{~F}_{100}$ decreased fresh bulb weight non-significantly by about 13.3 and $14.3 \%$, respectively in 2011 and by about 22.4 and $26.5 \%$, respectively in 2012 as compared to the treatment $\mathrm{I}_{100} \mathrm{~F}_{100}$.

The similar trend was also observed with leaf weight, number of leaves per plant and leaf length. Treatments $\mathrm{I}_{100} \mathrm{~F}_{75}$ and $\mathrm{I}_{85} \mathrm{~F}_{100}$ decreased leaf weight, number of leaves per plant and leaf length by about (11.1 and 13.5), (6.9 and 0.1) and (4.6 and $1.9 \%$ ), respectively in 2011 and by about (12.6 and 12.7\%), (5.1 and 8.1\%) and (8 and 10.8\%), respectively in 2012 as compared to the $\mathrm{I}_{100} \mathrm{~F}_{100}$ treatment. 
Table (7): Effect of different rates of irrigation and NPK fertilization on average fresh bulb weight, leaf weight, leaves per plant, leaf length and leaf diameter of onion after 60 days from transplanting.

\begin{tabular}{|c|c|c|c|c|c|c|c|c|c|c|}
\hline \multirow{2}{*}{ Treatments } & \multicolumn{2}{|c|}{ Fresh bulb weight, $\mathrm{g}$} & \multicolumn{2}{|c|}{ Leaf weight, $\mathrm{g}$} & \multicolumn{2}{|c|}{ Leaves per plant } & \multicolumn{2}{|c|}{ Leaf length, cm } & \multicolumn{2}{|c|}{ Leaf diameter, $\mathrm{cm}$} \\
\hline & 2011 & 2012 & 2011 & 2012 & 2011 & 2012 & 2011 & 2012 & 2011 & 2012 \\
\hline $\mathbf{I}_{100} \mathbf{F}_{100}$ & $22.10^{\mathrm{a}}$ & $23.92^{\mathrm{a}}$ & $54.88^{\mathrm{a}}$ & $56.45^{\mathrm{a}}$ & $7.13^{\mathrm{a}}$ & $7.26^{\mathrm{a}}$ & $45.69^{\mathrm{a}}$ & $48.67^{\mathrm{a}}$ & $1.03^{\mathrm{bcd}}$ & $1.42^{\mathrm{a}}$ \\
\hline $\mathbf{I}_{100} \mathbf{F}_{75}$ & $19.16^{\mathrm{ab}}$ & $18.57^{\mathrm{ab}}$ & $48.78^{\mathrm{ab}}$ & $49.34^{\mathrm{ab}}$ & $6.63^{\mathrm{ab}}$ & $6.89^{\mathrm{ab}}$ & $43.58^{\mathrm{abc}}$ & $44.78^{\mathrm{ab}}$ & $1.02^{\mathrm{bcd}}$ & $1.40^{\mathrm{a}}$ \\
\hline $\mathbf{I}_{100} \mathbf{F}_{50}$ & $12.43^{\mathrm{bc}}$ & $10.70^{\mathrm{bc}}$ & $43.58^{\mathrm{abc}}$ & $41.97^{\mathrm{ab}}$ & $6.43^{\mathrm{ab}}$ & $6.56^{\mathrm{abc}}$ & $43.44^{\mathrm{abc}}$ & $42.11^{\mathrm{bc}}$ & $1.06^{\mathrm{abcd}}$ & $1.01^{\text {bcde }}$ \\
\hline $\mathbf{I}_{100} \mathbf{F}_{0}$ & $9.72^{\mathrm{c}}$ & $13.00^{\mathrm{bc}}$ & $32.70^{\text {bcd }}$ & $40.84^{\mathrm{ab}}$ & $5.63^{\mathrm{b}}$ & $6.00^{\text {cde }}$ & $42.28^{\mathrm{abc}}$ & $41.89^{\mathrm{bc}}$ & $1.34^{\mathrm{ab}}$ & $0.99^{\text {cde }}$ \\
\hline $\mathbf{I}_{85} \mathbf{F}_{100}$ & $18.95^{\mathrm{ab}}$ & $17.57^{\mathrm{ab}}$ & $47.48^{\mathrm{ab}}$ & $49.29^{\mathrm{ab}}$ & $7.12^{\mathrm{a}}$ & $6.67^{\mathrm{abc}}$ & $44.81^{\mathrm{ab}}$ & $43.41^{\mathrm{bc}}$ & $1.24^{\mathrm{abc}}$ & $1.33^{\mathrm{ab}}$ \\
\hline $\mathbf{I}_{85} \mathbf{F}_{75}$ & $13.04^{\mathrm{bc}}$ & $13.81^{\mathrm{abc}}$ & $45.06^{\mathrm{abc}}$ & $45.64^{\mathrm{ab}}$ & $6.03^{\mathrm{ab}}$ & $6.37^{\text {bdde }}$ & $43.58^{\mathrm{abc}}$ & $43.22^{\mathrm{bc}}$ & $1.44^{\mathrm{a}}$ & $1.32^{\mathrm{abc}}$ \\
\hline $\mathbf{I}_{85} \mathbf{F}_{50}$ & $13.91^{\mathrm{bc}}$ & $12.61^{\mathrm{bc}}$ & $43.48^{\mathrm{abc}}$ & $40.15^{\mathrm{ab}}$ & $5.93^{\mathrm{ab}}$ & $6.22^{\text {bcde }}$ & $42.31^{\mathrm{abc}}$ & $41.33^{\mathrm{bcd}}$ & $1.39^{\mathrm{ab}}$ & $0.98^{\text {cde }}$ \\
\hline $\mathbf{I}_{85} \mathbf{F}_{0}$ & $10.59^{c}$ & $10.87^{\mathrm{bc}}$ & $32.71^{\mathrm{bcd}}$ & $39.61^{\mathrm{ab}}$ & $6.20^{\mathrm{ab}}$ & $6.11^{\text {bcde }}$ & $41.75^{\mathrm{abcd}}$ & $40.67^{\mathrm{bcd}}$ & $1.38^{\mathrm{ab}}$ & $0.97^{\mathrm{de}}$ \\
\hline $\mathbf{I}_{75} \mathbf{F}_{100}$ & $13.07^{\mathrm{bc}}$ & $13.46^{\mathrm{bc}}$ & $46.86^{\mathrm{ab}}$ & $48.27^{\mathrm{ab}}$ & $5.70^{\mathrm{b}}$ & $6.44^{\mathrm{abcd}}$ & $43.19^{\mathrm{abc}}$ & $43.11^{\mathrm{bc}}$ & $1.07^{\mathrm{abcd}}$ & $1.14^{\mathrm{abcd}}$ \\
\hline $\mathbf{I}_{75} \mathbf{F}_{75}$ & $8.90^{\mathrm{c}}$ & $10.18^{\mathrm{bc}}$ & $45.84^{\mathrm{abc}}$ & $46.99^{\mathrm{ab}}$ & $6.33^{\mathrm{ab}}$ & $6.11^{\text {bcde }}$ & $42.89^{\mathrm{abc}}$ & $43.11^{\mathrm{bc}}$ & $0.94^{\mathrm{cd}}$ & $1.10^{\mathrm{abcd}}$ \\
\hline $\mathbf{I}_{75} \mathbf{F}_{50}$ & $8.32^{\mathrm{c}}$ & $7.56^{\mathrm{bc}}$ & $37.79^{\text {abcd }}$ & $30.76^{\mathrm{b}}$ & $6.17^{\mathrm{ab}}$ & $6.00^{\text {cde }}$ & $42.19^{\mathrm{abc}}$ & $39.67^{\mathrm{cd}}$ & $1.10^{\mathrm{abcd}}$ & $0.88^{\mathrm{de}}$ \\
\hline $\mathbf{I}_{75} \mathbf{F}_{0}$ & $8.65^{\mathrm{c}}$ & $7.32^{\mathrm{bc}}$ & $31.81^{\mathrm{bcd}}$ & $30.65^{\mathrm{b}}$ & $5.70^{\mathrm{b}}$ & $5.89^{\text {cde }}$ & $38.14^{\text {cde }}$ & $36.86^{\mathrm{de}}$ & $1.03^{\mathrm{bcd}}$ & $0.86^{\mathrm{de}}$ \\
\hline $\mathbf{I}_{65} \mathbf{F}_{100}$ & $8.24^{\mathrm{c}}$ & $8.00^{\mathrm{bc}}$ & $45.90^{\mathrm{abc}}$ & $48.49^{\mathrm{ab}}$ & $6.37^{\mathrm{ab}}$ & $5.89^{\text {cde }}$ & $41.39^{\mathrm{abcd}}$ & $42.46^{\mathrm{bc}}$ & $0.84^{\mathrm{d}}$ & $1.08^{\mathrm{abcd}}$ \\
\hline $\mathbf{I}_{65} \mathbf{F}_{75}$ & $6.82^{\mathrm{c}}$ & $7.85^{\mathrm{bc}}$ & $30.49^{\text {bcd }}$ & $45.46^{\mathrm{ab}}$ & $6.43^{\mathrm{ab}}$ & $5.89^{\text {cde }}$ & $38.64^{\text {bcde }}$ & $42.16^{\mathrm{bc}}$ & $0.88^{\text {cd }}$ & $1.02^{\text {bcde }}$ \\
\hline $\mathbf{I}_{65} \mathbf{F}_{50}$ & $7.03^{\mathrm{c}}$ & $7.27^{\mathrm{bc}}$ & $26.69^{\mathrm{cd}}$ & $30.36^{\mathrm{b}}$ & $5.87^{\mathrm{b}}$ & $5.67^{\mathrm{de}}$ & $34.25^{\mathrm{e}}$ & $34.67^{\mathrm{e}}$ & $0.78^{\mathrm{d}}$ & $0.84^{\mathrm{de}}$ \\
\hline $\mathbf{I}_{65} \mathbf{F}_{0}$ & $6.59^{\mathrm{c}}$ & $6.24^{\mathrm{c}}$ & $23.93^{\mathrm{d}}$ & $29.10^{\mathrm{b}}$ & $5.97^{\mathrm{ab}}$ & $5.56^{\mathrm{e}}$ & $35.67^{\mathrm{de}}$ & $34.56^{\mathrm{e}}$ & $0.82^{\mathrm{d}}$ & $0.70^{\mathrm{e}}$ \\
\hline $\begin{array}{l}\text { F-test } \\
\text { Irrigation } \\
\text { Fertilization } \\
\text { Irri. } \times \text { Fert. } \\
\end{array}$ & $\begin{array}{l}* \\
* \\
* \\
\end{array}$ & $\begin{array}{c}\mathrm{NS} \\
* \\
* \\
\end{array}$ & $\begin{array}{c}\text { NS } \\
* \\
* \\
\end{array}$ & $\begin{array}{c}\mathrm{NS} \\
\mathrm{NS} \\
*\end{array}$ & $\begin{array}{c}\text { NS } \\
\text { NS } \\
*\end{array}$ & $\begin{array}{c}* \\
\mathrm{NS} \\
* \\
\end{array}$ & $\begin{array}{c}* \\
\mathrm{NS} \\
* \\
\end{array}$ & $\begin{array}{l}* \\
* \\
* \\
\end{array}$ & $\begin{array}{c}* \\
\mathrm{NS} \\
*\end{array}$ & $\begin{array}{l}* \\
* \\
* \\
\end{array}$ \\
\hline
\end{tabular}

NS and *: Non-significant, significant at $\mathrm{P}>0.05$, respectively. Means with the same treatment and column sharing the same letters are not significantly different at $\mathrm{P}<0.05$.

Table (8) shows the average values of neck thickness, bulb diameter, bulb length, bulb weight and split bulbs percentage after harvesting. The minimum values of neck thickness, bulb diameter, bulb length and bulb weight were $(1.05 \mathrm{~cm}, 43.25 \mathrm{~cm}, 72.5 \mathrm{~cm}$ and $63.68 \mathrm{~g})$ found with treatments $\mathrm{I}_{85} \mathrm{~F}_{50}, \mathrm{I}_{75} \mathrm{~F}_{0}, \mathrm{I}_{65} \mathrm{~F}_{75}$ and $\mathrm{I}_{65} \mathrm{~F}_{75}$, respectively in 2011 and were $(1.01 \mathrm{~cm}, 46.37 \mathrm{~cm}, 72.78 \mathrm{~cm}$ and $60.55 \mathrm{~g})$ found with treatment $\mathrm{I}_{100} \mathrm{~F}_{100}$, $\mathrm{I}_{65} \mathrm{~F}_{0}, \mathrm{I}_{65} \mathrm{~F}_{0}$ and $\mathrm{I}_{65} \mathrm{~F}_{0}$ in 2012, while the maximum values of neck thickness, bulb diameter, bulb length and bulb weight were $(1.79 \mathrm{~cm}$, $84.05 \mathrm{~cm}, 92.69 \mathrm{~cm}$ and $200.84 \mathrm{~g}$ ) found with treatments $\mathrm{I}_{75} \mathrm{~F}_{75}, \mathrm{I}_{100} \mathrm{~F}_{100}$, $\mathrm{I}_{100} \mathrm{~F}_{75}$ and $\mathrm{I}_{100} \mathrm{~F}_{100}$, respectively in 2011 and were $(1.65 \mathrm{~cm}, 77.77 \mathrm{~cm}$, 
$87.95 \mathrm{~cm}$ and $190.85 \mathrm{~g}$ ) found with treatments $\mathrm{I}_{100} \mathrm{~F}_{75}, \mathrm{I}_{100} \mathrm{~F}_{100}, \mathrm{I}_{100} \mathrm{~F}_{100}$ and $\mathrm{I}_{100} \mathrm{~F}_{100}$, respectively in 2012 .

Water levels and NPK fertilization did not significantly affect the formation of thick-necked bulbs in 2011 and 2012 (Table 8). In agreement with this assessment, Brewester (1987) reported that neck thickness is a physiological disorder that is influenced by seasons, sites and cultivars, not by fertility. In contrast, Jilani (2004) reported that increasing application of $\mathrm{N}$ increased the number of thick-necked bulbs. The similar trend was observed with the percent of split bulbs in 2011 and 2012 (Table 8).

As shown in table (8) there was no significant decrease of bulb weight with $\mathrm{I}_{100} \mathrm{~F}_{100}, \mathrm{I}_{100} \mathrm{~F}_{75}, \mathrm{I}_{100} \mathrm{~F}_{50}$, and $\mathrm{I}_{85} \mathrm{~F}_{100}$ treatments in 2011 but there was no significant decrease in bulb weight with the first five treatments in 2012. Treatments $\mathrm{I}_{100} \mathrm{~F}_{75}, \mathrm{I}_{100} \mathrm{~F}_{50}$ and $\mathrm{I}_{85} \mathrm{~F}_{100}$ decreased bulb weight by about 2.2, 5.5 and $14.6 \%$ in 2011 and by about $0.12,9.44$ and $9.6 \%$ in 2012 as compared to the $\mathrm{I}_{100} \mathrm{~F}_{100}$, respectively. Also, water stress and NPK fertilization significantly affected the bulb diameter and length. Treatment $\mathrm{I}_{100} \mathrm{~F}_{75}$ decreased non-significantly the diameter by about $3.2 \%$ in 2011 and by about $2.8 \%$ in 2012 as compared to the $\mathrm{I}_{100} \mathrm{~F}_{100}$ treatment, while water level significantly affected the bulb length and NPK fertilization had no affect but the interaction between water levels and NPK rates showed that the treatment $\mathrm{I}_{100} \mathrm{~F}_{75}$ increased the bulb length by about $3.7 \%$ in 2011 and decreased the bulb length by about $0.27 \%$ in 2012 as compared to the $\mathrm{I}_{100} \mathrm{~F}_{100}$ treatment (Table 8).

Growth parameters over all the treatments of this study were not significantly different between the $\mathrm{I}_{100} \mathrm{~F}_{100}, \mathrm{I}_{100} \mathrm{~F}_{75}$ and $\mathrm{I}_{85} \mathrm{~F}_{100}$ treatments in 2011 and 2012 (Table 7). Lower growth parameters were observed for the $65,75 \% \mathrm{ET}_{\mathrm{c}}, 0$, and $50 \%$ NPK treatments. Even though numerically higher growth parameters were observed with the $100 \%$ than with the 85 $\% \mathrm{ET}_{\mathrm{c}}$ treatments, they were not statistically different. Similar results were observed for these treatments, because the $100 \%$ and $85 \% \mathrm{ET}_{\mathrm{c}}$ treatments kept a same water moisture content at first and second layers $(0-10 \mathrm{~cm}$ and $10-20 \mathrm{~cm})$ and onions have shallower root $(30 \mathrm{~cm})$ systems (Fig. 2) and onion growth parameters were not affected. 
Table (8): Effect of different rates of irrigation and NPK fertilization on average neck thickness, bulb diameter and length and bulb weight of onion after harvested.

\begin{tabular}{|c|c|c|c|c|c|c|c|c|}
\hline \multirow[t]{2}{*}{ Treatments } & \multicolumn{2}{|c|}{$\begin{array}{c}\text { Neck thickness, } \\
\text { cm }\end{array}$} & \multicolumn{2}{|c|}{$\begin{array}{c}\text { Bulb diameter, } \\
\text { mm }\end{array}$} & \multicolumn{2}{|c|}{$\begin{array}{c}\text { Bulb length, } \\
\text { mm }\end{array}$} & \multicolumn{2}{|c|}{$\begin{array}{c}\text { Bulb weight, } \\
\text { g }\end{array}$} \\
\hline & 2011 & 2012 & 2011 & 2012 & 2011 & 2012 & 2011 & 2012 \\
\hline $\mathbf{I}_{100} \mathbf{F}_{100}$ & $1.15^{\mathrm{a}}$ & $1.01^{\mathrm{a}}$ & $84.05^{\mathrm{a}}$ & $77.77^{\mathrm{a}}$ & $89.35^{\mathrm{ab}}$ & $87.95^{\mathrm{a}}$ & $200.84^{a}$ & $190.85^{\mathrm{a}}$ \\
\hline$I_{100} F_{75}$ & $1.08^{\mathrm{a}}$ & $1.65^{\mathrm{a}}$ & $81.33^{\mathrm{a}}$ & $75.58^{\mathrm{a}}$ & $92.69^{\mathrm{a}}$ & $87.71^{a}$ & $196.57^{\mathrm{a}}$ & $190.62^{\mathrm{a}}$ \\
\hline$I_{100} F_{50}$ & $1.65^{\mathrm{a}}$ & $1.48^{\mathrm{a}}$ & $64.49^{\mathrm{d}}$ & $56.89^{\mathrm{bc}}$ & $79.11^{\text {de }}$ & $79.03^{\mathrm{abc}}$ & $189.84^{\mathrm{a}}$ & $172.82^{\mathrm{a}}$ \\
\hline$I_{100} F_{0}$ & $1.12^{\mathrm{a}}$ & $1.50^{\mathrm{a}}$ & $57.83^{\text {ef }}$ & $56.47^{\mathrm{bc}}$ & $77.76^{\mathrm{de}}$ & $77.21^{b c}$ & $137.85^{\mathrm{abcd}}$ & $148.82^{\mathrm{ab}}$ \\
\hline$I_{85} F_{100}$ & $1.59^{\mathrm{a}}$ & $1.08^{\mathrm{a}}$ & $72.45^{\mathrm{b}}$ & $75.04^{\mathrm{a}}$ & $87.69^{\mathrm{abc}}$ & $85.70^{\mathrm{ab}}$ & $171.45^{\mathrm{ab}}$ & $172.52^{\mathrm{a}}$ \\
\hline $\mathbf{I}_{85} \mathbf{F}_{75}$ & $1.35^{\mathrm{a}}$ & $1.31^{\mathrm{a}}$ & $68.67^{\mathrm{b}}$ & $72.83^{\mathrm{a}}$ & $81.84^{\mathrm{bcd}}$ & $85.50^{\mathrm{ab}}$ & $158.77^{\mathrm{abc}}$ & $120.10^{\mathrm{abc}}$ \\
\hline $\mathbf{I}_{\mathbf{8 5}} \mathbf{F}_{\mathbf{5 0}}$ & $1.05^{\mathrm{a}}$ & $1.46^{\mathrm{a}}$ & $61.00^{\mathrm{de}}$ & $56.40^{\mathrm{bc}}$ & $76.84^{\mathrm{de}}$ & $76.91^{\mathrm{bc}}$ & $95.15^{\text {cde }}$ & $93.15^{\mathrm{bc}}$ \\
\hline$I_{85} F_{0}$ & $1.37^{\mathrm{a}}$ & $1.58^{\mathrm{a}}$ & $56.21^{\mathrm{fg}}$ & $54.15^{\mathrm{bc}}$ & $76.09^{\mathrm{de}}$ & $76.78^{\mathrm{bc}}$ & $79.92^{\mathrm{de}}$ & $94.34^{\mathrm{bc}}$ \\
\hline $\mathbf{I}_{75} \mathbf{F}_{100}$ & $1.64^{\mathrm{a}}$ & $1.26^{\mathrm{a}}$ & $54.69^{\mathrm{fg}}$ & $66.89^{\mathrm{ab}}$ & $75.20^{\mathrm{de}}$ & $85.20^{\mathrm{ab}}$ & $101.02^{\text {bcde }}$ & $86.49^{\mathrm{bc}}$ \\
\hline $\mathbf{I}_{75} \mathbf{F}_{75}$ & $1.79^{a}$ & $1.24^{\mathrm{a}}$ & $54.27^{\mathrm{g}}$ & $64.82^{\mathrm{ab}}$ & $79.36^{\mathrm{de}}$ & $84.19^{\mathrm{ab}}$ & $99.49^{\text {cde }}$ & $80.13^{\mathrm{bc}}$ \\
\hline $\mathbf{I}_{\mathbf{7 5}} \mathbf{F}_{\mathbf{5 0}}$ & $1.54^{\mathrm{a}}$ & $1.59^{\mathrm{a}}$ & $55.16^{\mathrm{fg}}$ & $50.29^{c}$ & $79.72^{\text {cde }}$ & $75.53^{\mathrm{bc}}$ & $99.49^{\text {cde }}$ & $65.35^{\mathrm{c}}$ \\
\hline $\mathbf{I}_{75} \mathbf{F}_{0}$ & $1.19^{\mathrm{a}}$ & $1.15^{\mathrm{a}}$ & $43.25^{\mathrm{i}}$ & $47.31^{\mathrm{c}}$ & $72.67^{\mathrm{e}}$ & $75.39^{\mathrm{bc}}$ & $75.31^{\mathrm{de}}$ & $84.06^{\mathrm{bc}}$ \\
\hline $\mathbf{I}_{65} \mathbf{F}_{100}$ & $1.51^{\mathrm{a}}$ & $1.28^{\mathrm{a}}$ & $47.79^{\mathrm{h}}$ & $59.18^{\mathrm{bc}}$ & $73.89^{\mathrm{de}}$ & $82.37^{\mathrm{abc}}$ & $104.07^{\text {bcde }}$ & $79.92^{\mathrm{bc}}$ \\
\hline $\mathbf{I}_{65} \mathbf{F}_{75}$ & $1.26^{\mathrm{a}}$ & $1.37^{\mathrm{a}}$ & $46.71^{\mathrm{hi}}$ & $58.59^{\mathrm{bc}}$ & $72.50^{\mathrm{e}}$ & $80.98^{\mathrm{abc}}$ & $69.50^{\mathrm{de}}$ & $60.55^{c}$ \\
\hline$I_{65} F_{50}$ & $1.42^{\mathrm{a}}$ & $1.42^{\mathrm{a}}$ & $47.81^{\mathrm{h}}$ & $46.64^{\mathrm{c}}$ & $74.07^{\mathrm{de}}$ & $73.21^{\mathrm{c}}$ & $67.47^{\mathrm{de}}$ & $64.21^{\mathrm{c}}$ \\
\hline $\mathbf{I}_{65} F_{0}$ & $1.28^{\mathrm{a}}$ & $1.57^{\mathrm{a}}$ & $46.59^{\mathrm{hi}}$ & $46.37^{\mathrm{c}}$ & $79.58^{\mathrm{de}}$ & $72.78^{\mathrm{c}}$ & $63.68^{\mathrm{e}}$ & $66.90^{\mathrm{c}}$ \\
\hline $\begin{array}{l}\text { F-test } \\
\text { Irrigation } \\
\text { Fertilization } \\
\text { Irri. * Fert. }\end{array}$ & $\begin{array}{l}\text { NS } \\
\text { NS } \\
\text { NS }\end{array}$ & $\begin{array}{l}\text { NS } \\
\text { NS } \\
\text { NS } \\
\end{array}$ & $\begin{array}{l}* \\
* \\
*\end{array}$ & $\begin{array}{l}* \\
* \\
* \\
\end{array}$ & $\begin{array}{c}* \\
\mathrm{NS} \\
*\end{array}$ & $\begin{array}{l}\mathrm{NS} \\
* \\
*\end{array}$ & $\begin{array}{l}* \\
* \\
*\end{array}$ & $\begin{array}{c}* \\
\text { NS } \\
*\end{array}$ \\
\hline
\end{tabular}

NS and *: Non-significant, significant at $\mathrm{P}>0.05$, respectively. Means with the same treatment and column sharing the same letters are not significantly different at $\mathrm{P}<0.05$.

In conclusion, Pegue onion plant showed differential response to different water applied with different rates of NPK. Best response, as observed by the vegetative growth parameters of Pegue onion, was obtained when planting with treatment $\mathrm{I}_{100} \mathrm{~F}_{100}, \mathrm{I}_{100} \mathrm{~F}_{75}$ and $\mathrm{I}_{85} \mathrm{~F}_{100}$.

\section{Bulb yield of onion}

The bulb yield significantly ( $\mathrm{P}<0.05)$ increased with increasing applied water level while different rates of NPK did not significantly affect the bulb yield. The increase in yield was mainly because of a positive 
association between yield and yield attributing characters like bulb diameter, bulb length and bulb weight. In 2011, significantly higher bulb yields $(27.73,26.98,25.61,23.63$ and $21.83 \mathrm{t} / \mathrm{ha})$ were obtained with $\mathrm{I}_{100} \mathrm{~F}_{100}, \mathrm{I}_{100} \mathrm{~F}_{75}, \mathrm{I}_{100} \mathrm{~F}_{50}, \mathrm{I}_{100} \mathrm{~F}_{0}$ and $\mathrm{I}_{85} \mathrm{~F}_{100}$ treatments, respectively as shown in table (9). Lower yields were observed for the $65,75 \% \mathrm{ET}_{\mathrm{c}}, 0$ and 50\% NPK treatments. In 2011, even though numerically higher yield was observed with the $100 \%$ than with the $85 \% \mathrm{ET}_{\mathrm{c}}$ treatments, they were not statistically different. However, yields dropped significantly with the interaction of $65,75 \% \mathrm{ET}_{\mathfrak{c}}, 0$ and $50 \%$ NPK treatments.

Similar results were observed for these treatments in 2012, probably, because the $100 \%$ and $85 \% \mathrm{ET}_{\mathrm{c}}$ treatments has approximately the same soil moisture conditions (Fig. 2) and crop yields were not affected. However, yields dropped significantly with the $65,75 \% \mathrm{ET}_{\mathrm{c}}, 0$ and $50 \%$ NPK treatments in both seasons.

\section{Water use of onion}

There was significant effect of irrigation levels on WUE of onion (table 10) but there was no significant effect of NPK rates on WUE of onion in 2011 and 2012. The maximum WUE values were observed with 85 and $100 \% \mathrm{ET}_{\mathrm{c}}$ while the minimum values were observed with 65 and $75 \%$ $\mathrm{ET}_{\mathrm{c}}$ in the two years. As shown in table (10), when the water level decreased from $100 \% \mathrm{ET}_{\mathrm{c}}$ to $85 \% \mathrm{ET}_{\mathrm{c}}$, the treatment $\mathrm{I}_{85} \mathrm{~F}_{100}$ decreased non significantly the WUE by about $7.93 \%$ than treatment $\mathrm{I}_{100} \mathrm{~F}_{100}$ in 2011, while treatment $\mathrm{I}_{85} \mathrm{~F}_{100}$ increased non significantly the WUE by about $6.44 \%$ than treatment $\mathrm{I}_{100} \mathrm{~F}_{100}$ in 2012 .

Also as shown in table (10), when decreased the NPK rate from $100 \%$ to $75 \%$, the treatment $\mathrm{I}_{100} \mathrm{~F}_{75}$ was non significantly decreased the WUE by about $2.85 \%$ than treatment $\mathrm{I}_{100} \mathrm{~F}_{100}$ in 2011 , while treatment $\mathrm{I}_{100} \mathrm{~F}_{75}$ decreased non significantly the WUE by about $2 \%$ than treatment $\mathrm{I}_{100} \mathrm{~F}_{100}$ in 2012. Therefore, the same yield can be obtained without significant effect when decreasing the water irrigation by about $15 \%$ or by decreasing NPK fertilization by about $25 \%$. 
Table (9): Effect of different irrigation levels and NPK fertilization application on onion (var. Pegou) yield parameters (ton/ha).

\begin{tabular}{|c|c|c|c|c|}
\hline \multirow{2}{*}{ Treatments } & \multicolumn{2}{|c|}{ Split, ton/ha } & \multicolumn{2}{|c|}{ Total yield, ton/ha } \\
\hline & 2011 & 2012 & 2011 & 2012 \\
\hline $\mathbf{I}_{100} \mathbf{F}_{100}$ & $0.95^{\mathrm{a}}$ & $0.73^{\mathrm{a}}$ & $27.73^{\mathrm{a}}$ & $26.18^{\mathrm{a}}$ \\
\hline $\mathbf{I}_{100} \mathbf{F}_{75}$ & $0.77^{\mathrm{ab}}$ & $0.27^{\mathrm{b}}$ & $26.98^{\mathrm{a}}$ & $25.69^{\mathrm{a}}$ \\
\hline$I_{100} F_{50}$ & $0.30^{\mathrm{ab}}$ & $0.11^{b}$ & $25.61^{\mathrm{a}}$ & $23.15^{\mathrm{a}}$ \\
\hline $\mathbf{I}_{100} \mathbf{F}_{0}$ & $0.77^{\mathrm{a}}$ & $0.09^{b}$ & $23.63^{\mathrm{ab}}$ & $19.93^{\mathrm{ab}}$ \\
\hline$I_{85} F_{100}$ & $0.66^{\mathrm{a}}$ & $0.68^{\mathrm{ab}}$ & $21.83^{\mathrm{abc}}$ & $23.68^{\mathrm{a}}$ \\
\hline $\mathbf{I}_{85} \mathbf{F}_{75}$ & $0.46^{\mathrm{ab}}$ & $0.16^{\mathrm{b}}$ & $18.84^{\mathrm{abcd}}$ & $16.17^{\mathrm{abc}}$ \\
\hline $\mathbf{I}_{85} \mathbf{F}_{50}$ & $0.28^{\mathrm{ab}}$ & $0.11^{b}$ & $14.16^{\mathrm{bcd}}$ & $12.53^{\mathrm{bc}}$ \\
\hline $\mathbf{I}_{85} \mathbf{F}_{0}$ & $0.12^{b}$ & $0.05^{\mathrm{b}}$ & $13.38^{\mathrm{bcd}}$ & $12.63^{\mathrm{bc}}$ \\
\hline $\mathbf{I}_{75} \mathbf{F}_{100}$ & $0.17^{b}$ & $0.25^{\mathrm{b}}$ & $13.64^{\mathrm{bcd}}$ & $11.78^{\mathrm{bc}}$ \\
\hline $\mathbf{I}_{75} \mathbf{F}_{75}$ & $0.47^{\mathrm{ab}}$ & $0.08^{\mathrm{b}}$ & $13.73^{\mathrm{bcd}}$ & $10.76^{\mathrm{bc}}$ \\
\hline $\mathbf{I}_{\mathbf{7 5}} \mathbf{F}_{\mathbf{5 0}}$ & $0.19^{b}$ & $0.12^{\mathrm{b}}$ & $11.61^{\mathrm{cd}}$ & $8.83^{\mathrm{c}}$ \\
\hline $\mathbf{I}_{75} \mathbf{F}_{0}$ & $0.08^{b}$ & $0.06^{\mathrm{b}}$ & $10.73^{\mathrm{d}}$ & $11.27^{\mathrm{bc}}$ \\
\hline $\mathbf{I}_{65} \mathbf{F}_{100}$ & $0.14^{\mathrm{b}}$ & $0.14^{\mathrm{b}}$ & $12.82^{\mathrm{bcd}}$ & $10.80^{\mathrm{bc}}$ \\
\hline $\mathbf{I}_{65} \mathbf{F}_{75}$ & $0.12^{\mathrm{b}}$ & $0.06^{\mathrm{b}}$ & $9.39^{\mathrm{d}}$ & $8.13^{\mathrm{c}}$ \\
\hline $\mathbf{I}_{65} \mathbf{F}_{50}$ & $0.06^{\mathrm{b}}$ & $0.08^{b}$ & $9.06^{\mathrm{d}}$ & $8.64^{\mathrm{c}}$ \\
\hline $\mathbf{I}_{65} \mathbf{F}_{0}$ & $0.04^{\mathrm{b}}$ & $0.15^{\mathrm{b}}$ & $8.52^{\mathrm{d}}$ & $9.07^{\mathrm{c}}$ \\
\hline F-test & & & & \\
\hline Irrigation & NS & NS & $*$ & $*$ \\
\hline Fertilization & NS & NS & NS & NS \\
\hline Irri. * Fert. & $*$ & $*$ & $*$ & $*$ \\
\hline
\end{tabular}

NS and *: Non-significant, significant at $\mathrm{P}>0.05$, respectively. Means with the same treatment and column sharing the same letters are not significantly different at $\mathrm{P}<0.05$. 
Table (10): The influence of different applied water and different rates of NPK on WUE of onion.

\begin{tabular}{|c|c|c|}
\hline \multirow{2}{*}{ Treatments } & \multicolumn{2}{|c|}{ WUE, $\mathrm{kg} / \mathrm{m}^{3}$} \\
\hline & 2011 & 2012 \\
\hline$I_{100} F_{100}$ & $4.92^{\mathrm{a}}$ & $4.50^{\mathrm{a}}$ \\
\hline $\mathbf{I}_{100} \mathbf{F}_{75}$ & $4.78^{\mathrm{ab}}$ & $4.41^{\mathrm{ab}}$ \\
\hline $\mathbf{I}_{100} \mathbf{F}_{50}$ & $4.54^{\mathrm{abc}}$ & $3.98^{\mathrm{abc}}$ \\
\hline$I_{100} F_{0}$ & $4.19^{\text {abcde }}$ & $3.42^{\text {abcd }}$ \\
\hline $\mathbf{I}_{85} \mathbf{F}_{100}$ & $4.53^{\mathrm{abcd}}$ & $4.79^{\mathrm{a}}$ \\
\hline $\mathbf{I}_{85} \mathbf{F}_{75}$ & $3.91^{\text {abcde }}$ & $3.27^{\mathrm{abcd}}$ \\
\hline$I_{85} F_{50}$ & $2.94^{\text {bcde }}$ & $2.54^{\mathrm{bcd}}$ \\
\hline$I_{85} F_{0}$ & $2.78^{\text {cde }}$ & $2.56^{\mathrm{bcd}}$ \\
\hline $\mathbf{I}_{75} \mathbf{F}_{100}$ & $3.22^{\text {abcde }}$ & $2.70^{\mathrm{bcd}}$ \\
\hline $\mathbf{I}_{75} \mathbf{F}_{75}$ & $3.25^{\mathrm{abcde}}$ & $2.47^{\mathrm{bcd}}$ \\
\hline $\mathbf{I}_{75} \mathbf{F}_{50}$ & $2.74^{\text {cde }}$ & $2.03^{\mathrm{d}}$ \\
\hline$I_{75} F_{0}$ & $2.54^{\mathrm{de}}$ & $2.58^{\mathrm{bcd}}$ \\
\hline $\mathbf{I}_{\mathbf{6 5}} \mathbf{F}_{\mathbf{1 0 0}}$ & $3.48^{\text {abcde }}$ & $2.86^{\mathrm{abcd}}$ \\
\hline $\mathbf{I}_{65} \mathbf{F}_{75}$ & $2.55^{\mathrm{de}}$ & $2.15^{\mathrm{d}}$ \\
\hline$I_{65} F_{50}$ & $2.46^{\mathrm{de}}$ & $2.29^{\mathrm{cd}}$ \\
\hline $\mathbf{I}_{65} \mathbf{F}_{0}$ & $2.32^{\mathrm{e}}$ & $2.40^{\mathrm{bcd}}$ \\
\hline F-test & & \\
\hline Irrigation & $*$ & $*$ \\
\hline Fertilization & NS & NS \\
\hline Irri. * Fert. & $*$ & $*$ \\
\hline
\end{tabular}

\section{CONCLUSION}

\section{The study showed that:}

1. Calculated water irrigation requirements by FAO PenmanMonteith equation $\left(100 \% E T_{c}\right)$ was 564 and $582 \mathrm{~mm} / \mathrm{season}$ in 2011 and 2012, respectively.

2. There is no significant effect on growth and yield parameters when transit from $100 \%$ to $85 \% \mathrm{ET}_{\mathrm{c}}$ or $100 \%$ to $75 \%$ NPK rates.

3. Bulb weight, bulb diameter, bulb length, and yield were non significantly decreased from $100 \%$ to $85 \% \mathrm{ET}_{\mathrm{c}}$ or from $100 \%$ to $75 \%$ NPK rates in the two years (table 11).

4. The water use efficiencies (WUE) were deceased by increasing water irrigation applied in the two years. The maximum WUE was 
4.76 and $4.52 \mathrm{~kg} / \mathrm{m}^{3}$ for treatments $\mathrm{I}_{100} \mathrm{~F}_{100}$ and $\mathrm{I}_{85} \mathrm{~F}_{100}$ in 2011 and 2012, respectively, while the minimum value was 2.09 and 1.89 $\mathrm{kg} / \mathrm{m}^{3}$ for treatments $\mathrm{I}_{65} \mathrm{~F}_{0}$ and $\mathrm{I}_{75} \mathrm{~F}_{50}$ in 2011 and 2012, respectively.

Table (11): The treatments significantly did not affected by decreasing water level from 100 to $85 \% \mathrm{ET}_{\mathrm{c}}$ or by decreasing NPK rates from 100 to $75 \%$.

\begin{tabular}{|c|c|c|c|c|c|c|c|c|}
\hline \multirow[t]{2}{*}{ Treat. } & \multicolumn{2}{|c|}{$\begin{array}{c}\text { Bulb diameter, } \\
\text { cm }\end{array}$} & \multicolumn{2}{|c|}{$\begin{array}{c}\text { Bulb length, } \\
\text { cm }\end{array}$} & \multicolumn{2}{|c|}{$\begin{array}{c}\text { Bulb weight, } \\
\text { g }\end{array}$} & \multicolumn{2}{|c|}{$\begin{array}{l}\text { Yield, } \\
\text { ton/ha }\end{array}$} \\
\hline & 2011 & 2012 & 2011 & 2012 & 2011 & 2012 & 2011 & 2012 \\
\hline & 84.05 & 7777 & 893 & 8705 & 00 & 190.85 & 27. & 26 \\
\hline $\mathbf{I}_{100} \mathbf{F}_{75}$ & 81.33 & 75.58 & 92.69 & 87.71 & 196.57 & 190.62 & 26.98 & 25.69 \\
\hline $\mathbf{I}_{\mathbf{8 5}} \mathbf{F}_{100}$ & 72.45 & 75.04 & 87.69 & 85.70 & 171.45 & 172.52 & 21.83 & 23.68 \\
\hline $\mathbf{I}_{85} \mathbf{F}_{75}$ & 68.67 & 72.83 & 81.84 & 85.50 & 158.77 & 120.10 & 18.84 & 16.17 \\
\hline
\end{tabular}

\section{REFERENCES}

Allen, R.G.; L.S. Pereira; D. Raes and M. Smith. 1998. Crop evapotranspiration. Guidelines for computing crop water requirements. FAO Irrigation and Drainage. Paper No. 56, FAO, Rome, Italy, pp: 300.

Brewester, J. L. 1987. The effect of temperature on the rate of sprout growth and development within stored onion bulbs. Ann. App. Biol., 111: 463-465.

Costa, J.M.; M.F. Ortuno and M.M. Chaves, 2007. Deficit irrigation as a strategy to save water: physiology and potential application to horticulture. Journal of Integrative Plant Biology 49, 1421-1434.

Enciso, J.M.; J. Jifon and B. Wiedenfeld. 2007. Subsurface drip irrigation of onions: effects of drip tape emitter spacing on yield and quality. Agricultural Water Management 92 (3), 1-7.

Enciso, J. M.; B. Wiedenfeld; J. Jifon and S. Nelson. 2009. Onion yield and quality response to two irrigation scheduling strategies. Scientia Horticulturae 120 (2009) 301-305.

Hanson, B.; S. Orloff and D. Peters. 2000. Monitoring soil moisture helps refine irrigation management. California Agriculture 54 (3), 
$38-42$.

Jilani, M.S. 2004. Studies on the management strategies for bulb and seed production of different cultivars of onion (Allium cepa L.). $\mathrm{PhD}$ thesis, Gomal University, Dera Ismail Khan.

Kirda, C. 2000. Deficit irrigation scheduling based on plant growth stages showing water stress tolerance. Deficit Irrigation Practices, FAO Water Reports, Rome 22.

Kirda, C. 2002. Deficit irrigation scheduling based on plant growth stages showing water stress tolerance. pp. 3-10. In: Deficit Irrigation Practices. Water Reports no. 22, FAO, Rome, 108 p.

Kuchenbuch, R.; N. Claasen and A. Jungk. 1986. Potassium availability in relation to soil moisture. II Calculations by means of a mathematical simulation model. Plant and Soil, 95:233-243.

Lovelli, S.; M. Perniola; A. Ferrara and T. Di Tommaso. 2007. Yield response factor to water (Ky) and water use efficiency of Carthamus tinctorius L. and Solanum melongena L. Agric. Water Manage. 92, 73-80.

Lovelock, C.; M. Ball and I. Feller. 2006. Variation in hydraulic conductivity of mangroves: influence of species, salinity, and nitrogen and phosphorus availability. Physiol. Plantarum 127, $457-464$.

Martin, D.L.; E.C. Stegman and E. Fereres. 1990. Irrigation scheduling principles. ASAE Monograph published by the American Society of Agricultural Engineers, 1st edition, St. Joseph Mich, pp. 155-203.

Martin de Santa Olalla, F.J.; A. Domınguez-Padilla and R. Lopez. 2004. Production and quality of onion crop (Allium cepa L.) cultivated under controlled deficit irrigation conditions in a semiarid climate. Agricultural Water Management 68, 77-89.

McQuate, G.T.; P.F. Germann and E.F. Connor. 1986. Soybean cell sap response to water deficits. J. Plant Physiol. 125:105-114.

Mpelasoka, B.S.; M.H. Behboudian and S.R. Green. 2001. Water 
use, yield and fruit quality of lisimeter-grown apple trees: responses to deficit irrigation and crop load. Irrigation Science 20, 107-113.

Patanè, C. and S.L. Cosentino. 2010. Effects of soil water deficit on yield and quality of processing tomato under a Mediterranean climate. Agric. Water Manage. 97, 131-138.

Pereira, L.S.; T. Oweis and A. Zairi. 2002. Irrigation management under water scarcity. Agricultural Water Management 57, 175206.

Sammis, T. W; M.S. Al-Jammal; S. Ball and D. Smeal. 2000. Crop water use of onion. In: Proceedings of sixth International Micro Irrigation Congress, Micro 2000, Cape Town, South Africa, 22 27 October 2000, pp. 1-9.

Topcu, S.; C. Kirda; Y. Dasgan; H. Kaman; M. Cetin; A. Yazici and M. A. Bacon. 2007. Yield response and $\mathrm{N}$ fertilizer recovery of tomato grown under deficit irrigation. European Journal of Agronomy 26, 64-70.

Zegbe-Dominguez, J. A.; M. H. Behboudian; A. Lang and B. E. Clothier. 2003. Deficit irrigation and partial root zone drying maintain fruit dry mass and enhance fruit quality in 'Petopride' processing tomato (Lycopersicon esculentum Mill.). Sci. Hort. 98, 505-510.

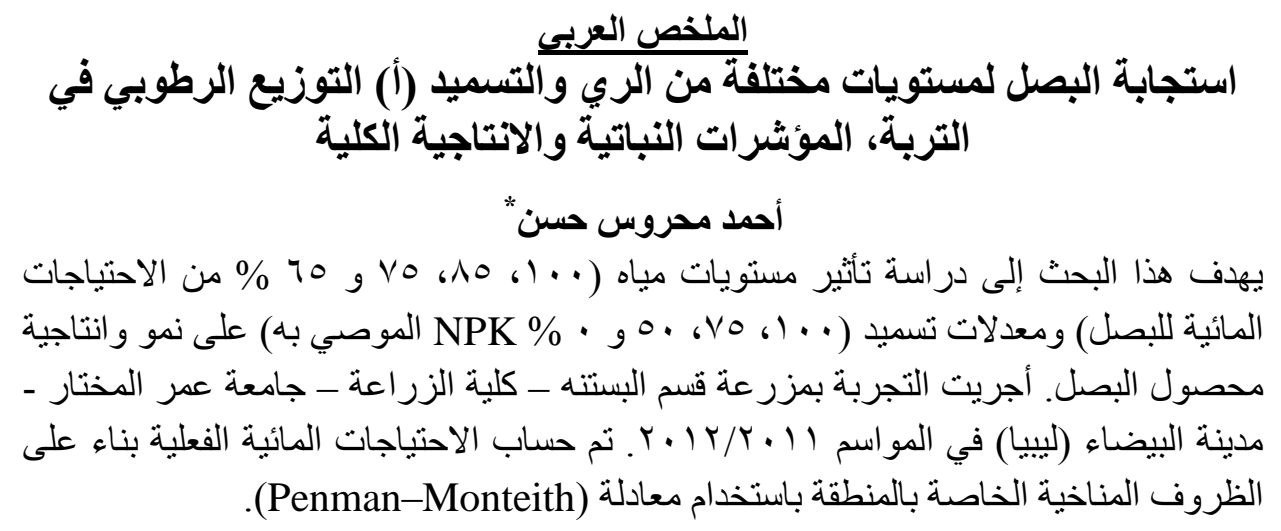

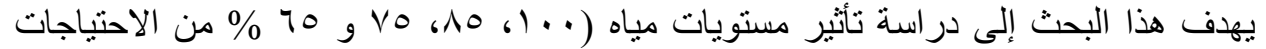

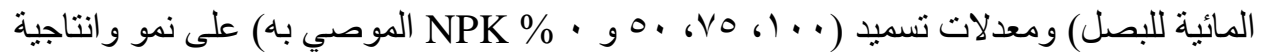

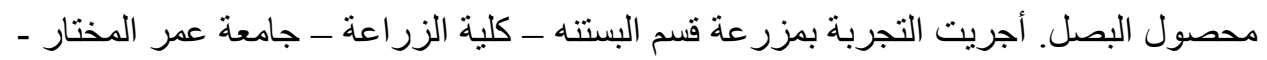

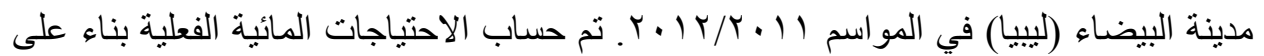

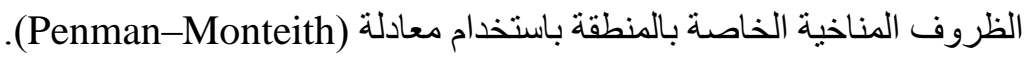

* مدرس بقسم الهندسة الزراعية ـ كلية الزراعة - جامعة القاهرة. 


\section{وقد بينت الار اسة ما يلي:}

ا. كانت الاحتياجات المائية المحسوبة بمعادلة (FAO Penman-Monteith) للبصل

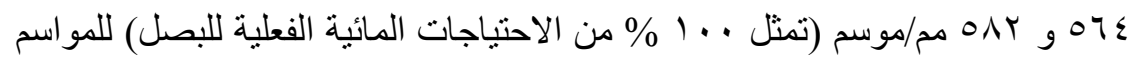

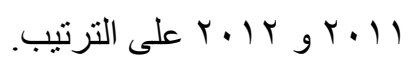

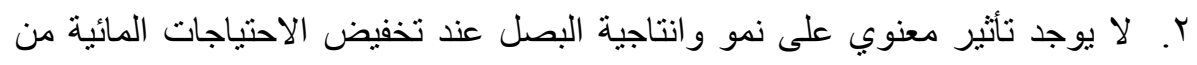

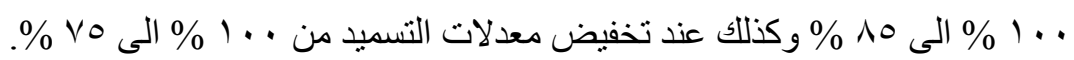

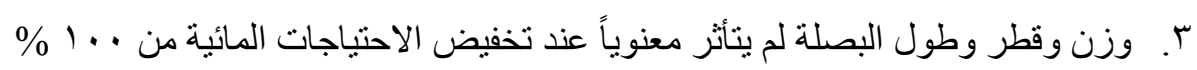

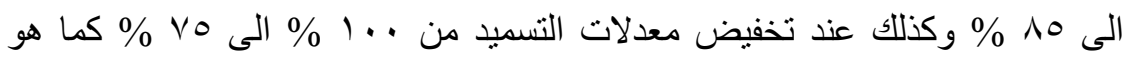

$$
\text { موضتح بالجدول (1) (1). }
$$

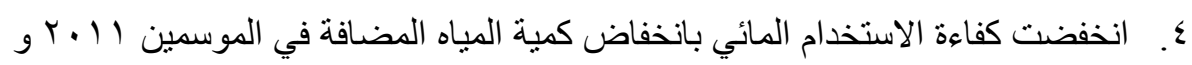

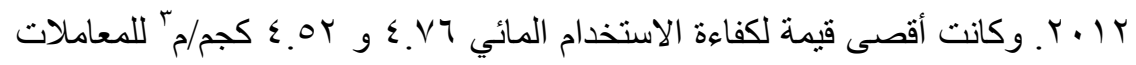

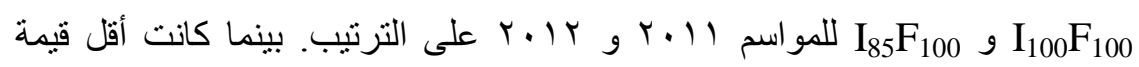

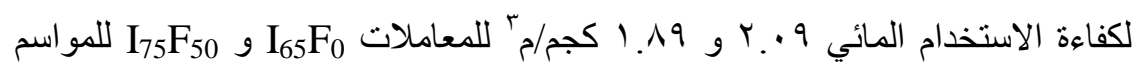
11 